УДК 004.942.519.87(045)

\author{
А. І. Кузьмичов, Є. О. Аодонов \\ Інститут проблем реєстрації інформації НАН України \\ вул. М. Шпака, 2, 03113 Київ, Україна \\ e-mail: akuzmychov@gmail.com
}

\title{
Оптимізаційні моделі реконфігурації мережевих структур
}

\begin{abstract}
Запропоновано оптимізаційні моделі інтегрованих задач розміщення центрів з надання послуг (серверів) у мережевій структурі з одночасною прив'язкою клієнтів до серверів, щуо побудовані в доступному та потужному середовищі електронних таблищь для формування організаційно-управлінських рімень $і$ забезпечення гнучкого режиму функиіонування комунікаційної системи шляхом ї̈ реконфігурації-визначення її оновлених структури та функщій.
\end{abstract}

Ключові слова: оптимізаційні задачі розміщення серверів і призначення клієнтів (location/allocation problems), реконфігурачія мережі, системи та центри надання послуг, електронно-табличне моделювання mа оптимізація (spreadsheet modeling and optimization).

\section{Вступ}

На відміну від виробничих, досить сталих організаційних і технологічних схем, логістична індустрія визначається розмаїттям таких схем, де навіть один крупний проект в умовах невизначеності має декілька варіантів реалізації і кожен 3 них висуває конкретні вимоги до мереж, що застосовуються. Тож основою та навіть принципом конкурентної переваги в індустрії надання послуг є неперервні зміни, зокрема, раціональні зміни бізнес-моделей, які мають здійснюватися у діючій логістичній мережі оперативним персоналом. Звідси висувається потреба мати набір доступних і ефективних обчислювальних інструментів для розв'язання типових задач мережевої оптимізації особами, які приймають рішення з управління потоками в ланцюгах постачання безпосередньо на робочому місці.

Нижче показано, що платформа електронних таблиць (ЕT) із вбудованими чи довантажуваними спеціалізованими програмами-надбудовами є сучасним і потужним інструментальним середовищем, доступним на звичайному ПК будь-якому користувачеві-дослідникові.

Процес надання послуг на різних рівнях функціонування організацій здійснюється двома основними учасниками, де різноманітні об'єкти-сервери (виробничі потужності, склади, вокзали та порти, постачальники та розподільчі центри, 
хаби, лікарні, школи, facility) надають послуги відповідним об’єктам-клієнтам, використовуючи наявні комунікації між ними у вигляді мереж. За методами сервіс-менеджменту, сучасної і науково обгрунтованої технології з організаційного управління інфраструктурними об'єктами, формуються направлені потоки послуг, за бізнес-моделлю визначаються витрати для функціонування систем колективного обслуговування та показники ефективності. Сфера послуг охоплює торгівлю, транспорт і зв'язок, освіту, науку, охорону здоров'я, безпеку і оборону, фінанси тощо. Організаційні структури систем надання послуг є складними та різноманітними, і загалом, у національних економіках можуть бути економічно важливішими за структури матеріального виробництва, скажімо, у США сфера послуг сягає $80 \%$ ВВП.

\section{Реконфігурація мережі: проблема та реамізація}

Ділення всіх вузлів мережі і об’єктів у них на два класи - сервери та клієнти - тимчасове та досить штучне, бо у складно-організованих системах зі змінюваною та багаторівневою оргструктурою і функціями у часі та/чи просторі для розв'язання функціональних задач завжди формуються потоки із різними властивостями та виміром, де певний вузол мережі може неодноразово змінювати свій статус і бути одночасно сервером певного призначення із відповідною клієнтурою чи клієнтом певного сервера вищого рівня. Наприклад, магазин роздрібної торгівлі є сервером для мешканців прилеглих будинків і, одночасно, клієнтом міжрегіонального логістичного центру, ряду підприємств, банків чи оптових ринків.

Проблема реконфігурації системи «сервери-клієнти» виникає, коли сформована стала мережева структура змінюється й слід майже миттєво врахувати ці зміни для коректного відображення реальної ситуації, скажімо, поновити електропостачання населених пунктів, порушеного із-за непогоди. Або, постачальник послуг змінив профіль, змінилася пропускна здатність каналу зв'язку, аналогічні послуги пропонує щойно відкритий логістичний центр із розгалуженою структурою, змінилася конфігурація транспортної мережі тощо - на це треба реагувати якнайшвидше та зважено.

Ця проблема, зокрема, напряму стосується живучості комунікаційних мереж, де змінюються властивості, параметри та функції їхніх складових - вузлів і дуг - за самих різних причин, за прикрих аварій чи цілеспрямованих атак.

Тож ця проблематика із середини 1960-х рр. визначила науково-орієнтований прикладний напрямок location analysis [1-6], що охоплює практично усі сфери життя людей і суспільства, від харчування і медицини до транспортної логістики та військової справи, від побутового мережевого маркетингу до стратегічних мережевих воєн.

Відповідна теорія цього аналізу зазвичай ставить дві спряжені оптимізаційні задачі:

- локації серверів відносно клієнтів (location): Скільки треба розташувати серверів? Де і які розташувати сервери?;

— прив'язки клієнтів до серверів (allocation): Як розподілити попит клієнтів між серверами? Хто ким/чим має обслуговуватися?

за відповідним критерієм. 
На етапі проектування мережевої структури визначаються базова конфігурація: кількість і місця розміщення у певних вузлах мережі обслуговуючих об'єктів чи засобів (серверів), що надають послуги прикріпленим до них вузламклієнтам згідно їхнього попиту на споживання цих послуг за заданими пропозиціями та попитом. Таким чином, на кожному часовому етапі горизонту планування чітко визначені функції усіх вузлів (джерел, стоків, транзитних пунктів) i зв'язки між ними для передачі потоків відповідними комунікаціями; приклади: магістральні та розподільчі нафто-, газо- та водопроводи, шляхове господарство, ЛЕП, телефонний зв'язок, водний і повітряний транспорт тощо.

Проблеми реконфігурації виникають при поточній експлуатації мережі постачання, коли можливі звичайні, передбачені нормами та сценаріями, чи, рідше, але із більш впливовими наслідками, нештатні чи надзвичайні ситуації, події зі стихійним характером, коли в усталеній хоча б тимчасово конфігурації «сервериклієнти» вимушено перерозподіляються функції серверів і клієнтів з одночасною зміною маршрутів, бо ж умить різко змінилися ресурсні можливості серверів, попит клієнтів на споживання відповідних послуг чи реальні властивості комунікацій. Причини виникнення таких ситуацій різні, це: непередбачувані погодні умови, аварії, вихід з ладу одного обладнання й перенавантаження іншого як наслідок, порушення договірної дисципліни чи некваліфіковане обслуговування, аж до терористичних актів, свідомо направлених на пошкодження чи навіть знищення певних складових мережі. I завжди виникає проблема якнайкращого (оптимального) реагування на ці ситуації, враховуючи часові і ресурсні обмеження, шляхом проведення відповідних оперативних розрахунків для формування відповідальних і зважених рішень, які мають бути прийняті.

Критерій оптимізації може бути один чи декілька, у багатокритеріальній задачі оптимізації одночасно треба прийняти рішення щодо їхнього здійснення за несумісних умов: скажімо, клієнти бажають, аби надання послуги обійшлося якнайдешевше, комфортно та з якістю високого рівня, і тоді в режимі діалогу відшукується компромісне рішення.

Найчастіше критерієм оптимальності задач про розміщення центрів обслуговування є мінісум, де мінімізується сума зважених втрат чи витрат із надання комунікаційних та інших послуг серверами оточуючим їх вузлам-кліснтам. Інші критерії: мінімакс, коли мінімізуються витрати в інтересах найвіддаленіших клієнтів при розміщенні «корисних» центрів, чи максимін, якщо треба розмістити якнайдалі розміщувані об'єкти зі шкідливими чи небезпечними властивостями від ближчих до них клієнтів.

Звичайно кількість розмімуваних серверів різна, від одного загального для усіх клієнтів, до кількох $(k)$, кожен з яких обслуговує виокремлену груп клієнтів. Відповідно, відшукуються місця розташування $k$ центрів обслуговування, де $k-$ задана чи шукана кількість серверів: якщо вона задана, тоді потенційними місцями розташування є усі або ж визначені вузли-кандидати, якщо ж ця кількість шукана, то треба знайти координати цих місць, і відповідні обчислення значно складніші.

Суттєву роль при розробці оптимізаційної моделі, яку треба реалізувати наявними комп'ютерними засобами, відіграють характеристики простору рімень (неперервний, дискретний), це: площина $X, Y$ (евклідів простір) із доступною 
будь-де точкою з координатами $\left(x_{i}, y_{i}\right)$ чи діюча мережа з обмеженим набором потенційних вузлів для прийняття рішення: бути/не бути у них серверу.

У першому (неперервному) випадку маємо теоретичну можливість ідеально розмістити сервер, дискретний варіант більш розповсюджений і краще пристосований для обчислень.

У свою чергу, мережу (типу повного графу) представляють квадратною матрицею відстаней, що побудована за координатами вузлів, де потенційно існують зв'язки між усіма парами вузлів, звідси - серйозні вимоги до розміру задачі та машинної пам'яті. Інший варіант, кращий для практики, коли мережа відтворює існуючу структуру та комунікації, наприклад, неорієнтовану чи змішану транспортну, соціальну чи інформаційну систему, тоді у розрахунках використовується спискова структура даних, значно менша за розмірами.

Цільова функція, значення якої зазвичай мінімізується ${ }^{1}$, це загальна вартість розміщення серверів і прикріплення до них клієнтів, яка складається із комунікаційних витрат «сервер $\rightarrow$ клієнти» на дугах i, можливо, витрат на створення й облаштування самих серверів у вузлах, які розрізняються залежно від попиту та властивостей (природних, демографічних, економічних) клієнтів та від типу й властивостей розміщуваного сервера, наприклад, необхідної системи енергопостачання, мобільного чи поштового зв'язку та, зрозуміло, транспорту. Тож звичайно відшукується оптимальна конфігурація мережі за критерієм мінімізації загальних витрат з урахуванням обмежень на шукані невідомі змінні.

В умовах реконфігурації мережі, тобто, вимушеного відхилення від знайденого оптимуму, загальні витрати неодмінно зростуть, і розв'язанням оптимізаційної задачі з оновленими початковими даними визначається найкращий вихід із ситуації, що склалася.

В освіті і для оперативного розв'язання оптимізаційних задач фахівцямипрактиками сформувалась інформаційна технологія електронно-табличного моделювання [7,8], де ефективно застосовуються спеціальні програми-надбудови 3 фіксованої структурою, це: 1) шукані невідомі; 2) цільова функція; 3) обмеження та граничні умови. Ця технологія — неодмінна складова навчальних програм 3 OR/MS [5] і бізнес-аналітики.

Зокрема, навчальна версія надбудови Excel Solver (Поиск решения), що розроблена компанією Frontline Systems на початку 1990-х рр., є складовою популярних табличних процесорів, правда, можливості цієї версії обмежуються 200 шуканими змінними і 100 обмеженнями, зате промислова версія (платформа ASP) містить широкий набір математичних методів і обчислювальних алгоритмів для розв'язання задач з тисячами невідомих. Популярність цієї технології в управлінській діяльності та підтримка компанії IBM привели до потужного процесу розробки альтернативних free-версій таких надбудов, наприклад, оптимізатора OpenSolver для реалізації моделей лінійної і цілочислової оптимізації, повністю узгодженого з Excel Solver, який навіть застосовується у навчальних програмах ВН3 [7].

\footnotetext{
${ }^{1}$ Перша в історії математики задача локації: «На площині задано три точки, знайти четверту, щоби сума відстаней від неї до трьох заданих точок була мінімальна», поставлена П. Ферма (1607-1665).
} 


\section{Розміщення серверів у повному графі}

Постановка задачі.

Задано мережу $G=(N, A)$ із $|N|=n$ зважених вузлів і $|A|=m=n^{2}$ зважених дуг, де початкові дані:

$V=\left\{v_{i j}\right\}, i, j=1, \ldots, n-$ вагові коефіцієнти дуг (наприклад, довжина), це повна матриця відстаней між вузлами розміром $(n \times n)$;

$k$ - кількість серверів $(1 \leq k \leq n)$;

$P=\left\{p_{i}\right\}$ - вагові коефіцієнти вузлів (попит).

Треба розмістити у $k$ вузлах із $n$ вузлів-кандидатів сервери для задоволення попиту $m$ клієнтів, визначивши: сервер;

— вектор розміщення $Y=\left\{y_{i}\right\}, i \in N$, де $y_{i}=1$, якщо у $i$-му вузлі розміщено клієнта,

— матрицю призначення $X=\left\{x_{i j}\right\}$, де $x_{i j}=1$, якщо $i$-й сервер обслуговує $j$-го щоб мінімізувати суму зважених відстаней між серверами й клієнтами.

Пропозиції серверів необмежені.

Це задача лінійного цілочисельного (булева) програмування.

\section{Задача оптимізації}

I. Знайти $Y=\left\{y_{i}\right\}$ та $X=\left\{x_{i j}\right\}$, щоб

II. ЦФ $F(X, Y)=\sum_{i=1}^{n} \sum_{j=1}^{n} p_{i} v_{i j} x_{i j} \rightarrow \min$

III. За обмежень:

$$
\begin{aligned}
& \sum_{i=1}^{n} x_{i j}=1, \\
& \sum_{j=1}^{n} x_{i j} \leq n y_{i}, i, j=\overline{1, n}, \\
& \sum_{i} y_{i}=k
\end{aligned}
$$

та граничних умов: $x_{i j}, y_{i} \in\{1,0\}$.

Приклад.

Мережа утворена з 25-ти районних центрів Київської області, де «вагою» вузла $є$ чисельність населення району (рис. 1).

Для розрахунків визначено матрицю відстаней розміром $(25 \times 25)$ між вузлами.

Треба знайти місця розташування 5-ти серверів і схему прикріплення клієнтів до серверів, мінімізувавши витрати на розподіл і забезпечення замовлень на послуги. Розмір задачі: 650 змінних, $625(X)+25(Y)$, перебільшує обмеження вбудованого оптимізатора Поиск решения у 200 змінних, тому надалі застосовуємо надбудову OpenSolver.

Результат розв'язку задачі показано на рис. 2. 


\begin{tabular}{|c|c|c|c|}
\hline Район & Центр & Чисельнність & \\
\hline Бариштівський & Баришшівка & 36077 & \\
\hline Білоцерківськй & Біла Церква & 48619 & \\
\hline Богуславськй & Богуслав & 35022 & \\
\hline Бориспільський & Бориспіль & 53188 & \\
\hline Бородянський & Бородянка & 57388 & \\
\hline Броварський & Бровари & 67998 & \\
\hline Васильківський & Васильків & 57811 & \\
\hline Володарський & Володарка & 17555 & \\
\hline Вишшородськй & Вишшород & 73166 & \\
\hline Згурівський & Згурівка & 16830 & \\
\hline Іванківський & Іванків & 30149 & \\
\hline Кагарлищький & Кагарлик & 33521 & \\
\hline К.-Святошинський & Киї & 167544 & \\
\hline Макарівський & Макарів & 37005 & \\
\hline Миронівський & Миронівка & 34465 & \\
\hline Обухівський & O6yxiв & 35850 & \\
\hline П.-Хмельнищький & П.-Хмельнищький & 28383 & \\
\hline Поліський & Красятичі & 5781 & \\
\hline Рокитнянський & Poкитне & 27615 & \\
\hline Сквирський & Cквира & 37504 & \\
\hline Ставищенський & Ставище & 22493 & \\
\hline Тарашанський & Tараща & 28676 & \\
\hline Тетіївський & Teтiïs & 31927 & \\
\hline Фастівський & Фастів & 30789 & \\
\hline Яготинський & Яroтин & 33334 & \\
\hline
\end{tabular}

Рис. 1. Початкові дані про мережу
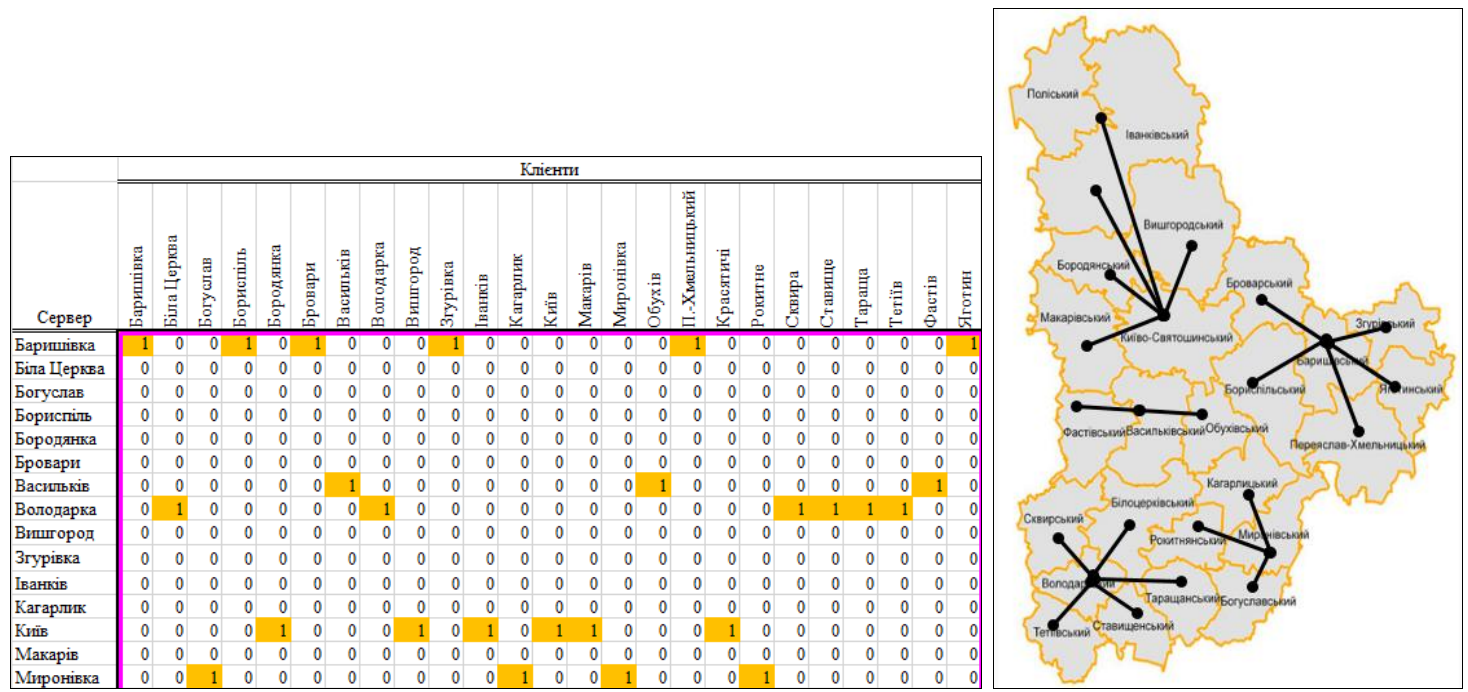

Рис. 2. Оптимальне розміщення 5-ти серверів для обслуговування 25-ти клієнтів (показано фрагмент матриці) 


\section{Аналіз результату}

I. Визначено вектор розміщення: $Y=(1,7,8,13,15)$ та матрицю призначення $X$; оптимальне прикріплення клієнтів до серверів показано на рис. 2.

II. Загальні мінімальні витрати 2445591,9

III. Усі обмеження задоволені.

Тривалість 20 сек.

Тут і нижче: реконфігурація мережі - це модифікація базової моделі (1), де введенням додаткових обмежень відшукується новий оптимальний план, зрозуміло, із гіршим значенням ЦФ порівняно зі знайденим оптимумом.

\section{Модифікація моделі}

Мета: визначити змінену конфігурацію розміщення серверів згідно умов, що склалися.

Умова: за ситуацією, що виникла, сервер у вузлі 1 (Баришівка), який обслуговував цей вузол і ще 5 клієнтів, припиняє своє функціонування, і цей вузол тепер має стати клієнтом іншого сервера, як і інші 5 клієнтів.

Вводимо обмеження: $y_{1}=0$ і отримуємо оновлений результат (рис. 3 ).
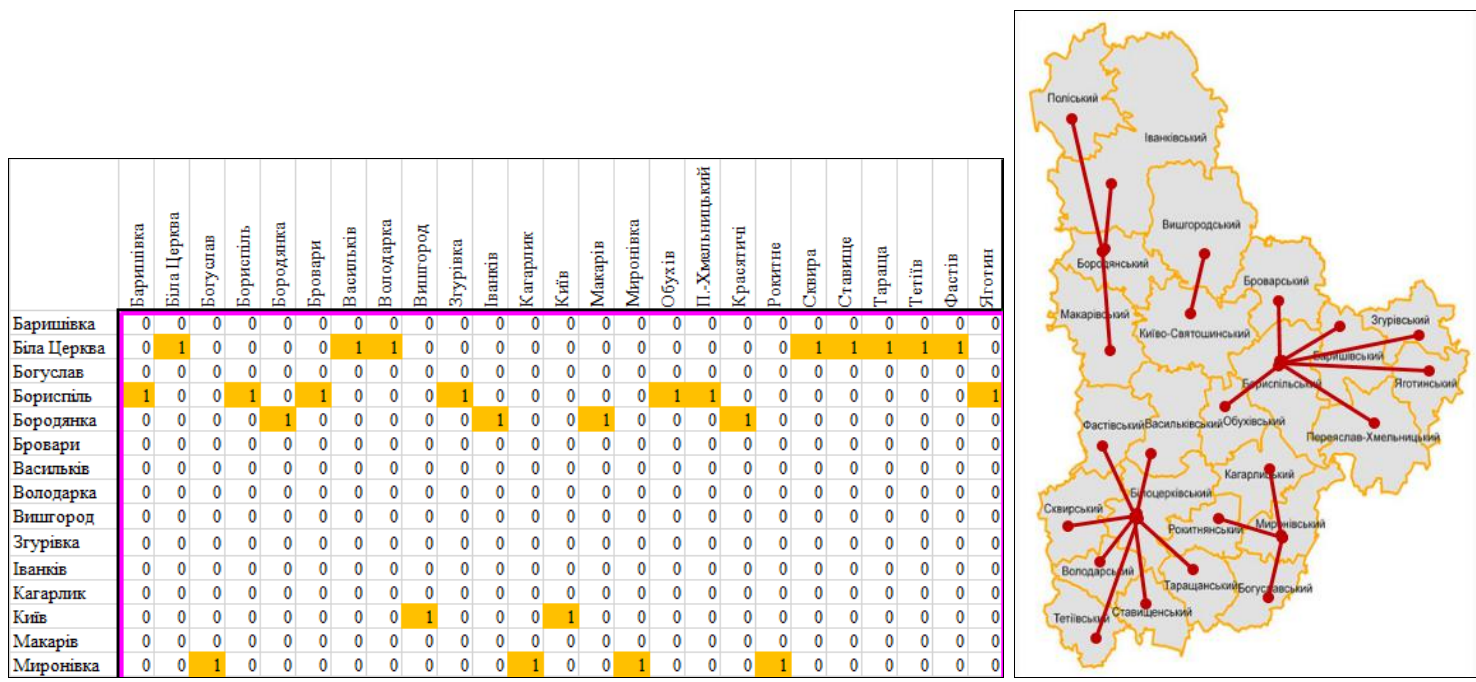

Рис. 3. Зміна статусу сервера у вузлі 1 та його колишніх клієнтів

Розміщення серверів: $Y=(2,4,5,13,15), Ц Ф=2539217,4$.

Зауваження: для цієї «ідеальної» моделі характерна властивість - оскільки пропозиції кожного сервера необмежені, тож чим більше серверів, тим меншими будуть комунікаційні витрати, при $k=1$ вони найбільші, коли $є$ один центр для усіх клієнтів, при $k=n$ - дорівнюють нулю, де кожен вузол-клієнт самодостатній.

\section{Розміщення серверів у повному графі з обмеженнями}

Ідеалізована задача розміщення/розподілу «приземлюється» додаванням реальних умов, бо кожен вузол-кандидат має власні властивості/можливості у вигля- 
ді вагових коефіцієнтів, які мають враховуватися в обмеженнях на шукані змінні та у цільовій функції для обчислення витрат при шуканому розміщенні серверів.

Можливості вузла бути сервером визначає коефіцієнт $r_{i}$ - це наявний запас споживаної клієнтами послуги (ресурсу), який має сервер, якщо його розміщувати у $i$-му вузлі, наприклад, питної води, електрики, обігових коштів чи необхідного кваліфікованого персоналу організації (лікарні, школи, підприємства). Відповідно, у базову модель задачі оптимізації (1) додається обмеження $\sum_{j=1}^{n} p_{i} x_{i j} \leq r_{i} y_{i}$ для прикріплених $j$-х клієнтів, які будуть отримувати послугу від щойно утвореного сервера в $i$-му вузлі.

Приклад. Сумарний попит 25-ти клієнтів складає 1036 од. (\% від населення), визначити 5 вузлів для розміщення стандартного серверного обладнання потужністю $r=300$ од. (рис. 4).
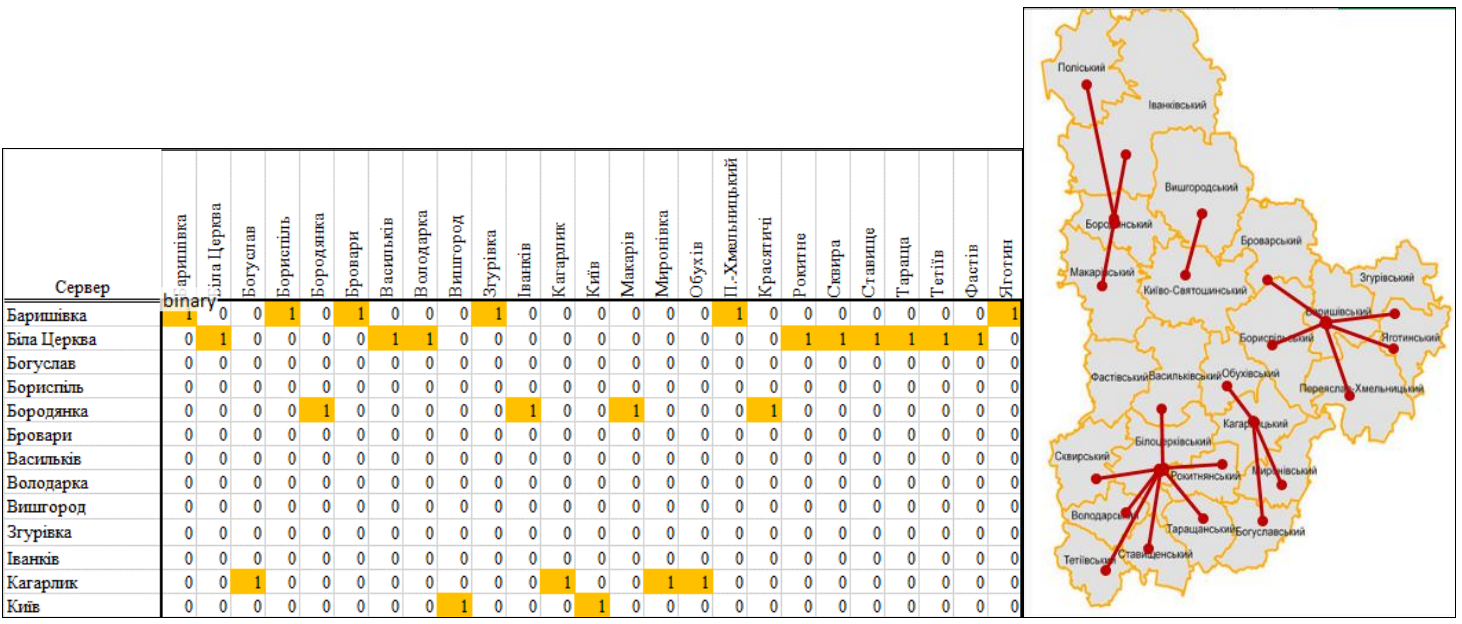

Рис. 4. Розташування серверів (фрагмент таблиці)

Розподіл обладнання:

\begin{tabular}{|l|r|r|r|}
\hline Сервер & Викор. & Попит & Залишки \\
\hline Бариштівка & 233 & 36 & 67 \\
\hline Біла Церква & 297 & 48 & 3 \\
\hline Бородянка & 129 & 57 & 171 \\
\hline Кагарлик & 137 & 33 & 163 \\
\hline Киї & 240 & 167 & 60 \\
\hline Разом: & $\mathbf{1 0 3 6}$ & $\mathbf{3 4 1}$ & $\mathbf{4 6 4}$ \\
\hline
\end{tabular}

Властивості вузла бути сервером визначає також ваговий коефіцієнт $z_{i}-$ фіксовані витрати на будівництво і облаштування сервера в $i$-му вузлі. Для його врахування цільова функція задачі оптимізації змінюється на

$$
S=\sum_{i=1}^{n} \sum_{j=1}^{n} p_{i} v_{i j} x_{i j}+\sum_{i=1}^{n} z_{i} y_{i} \rightarrow \min .
$$


Приклад. Витрати на будівництво і облаштування сервера складають 500 тис. грн. Визначено кращий варіант розташування сервера (рис. 5).

За цих умов Миронівка замінила Кагарлик.

\begin{tabular}{|c|c|c|c|c|c|c|c|c|c|c|c|c|c|c|c|c|c|c|c|c|c|c|c|c|c|}
\hline Сервер & 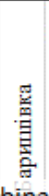 & 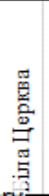 & $\begin{array}{l}0 \\
5 \\
3 \\
3 \\
0\end{array}$ & $\begin{array}{l}\text { 直 } \\
\text { 总 } \\
\text { 总 }\end{array}$ & 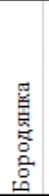 & $\begin{array}{l}\text { 言 } \\
\text { 总 } \\
\text { 号 }\end{array}$ & 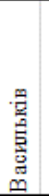 & 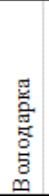 & 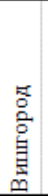 & 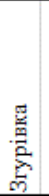 & 兽 & 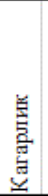 & 唼 & 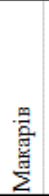 & 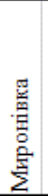 & 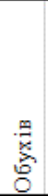 & 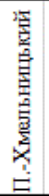 & 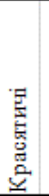 & 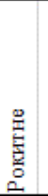 & 莒 & 曽 & 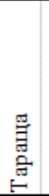 & 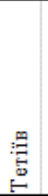 & 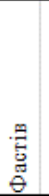 & 㤩 \\
\hline Бариштівка & bina & $y \overline{0}$ & 0 & 1 & 0 & 1 & 0 & 0 & 0 & 1 & 0 & 0 & 0 & 0 & 0 & 0 & 1 & 0 & 0 & 0 & 0 & 0 & 0 & 0 & 1 \\
\hline Біла Церква & 0 & 1 & 0 & 0 & 0 & 0 & 1 & 1 & 0 & 0 & 0 & 0 & 0 & 0 & 0 & 0 & 0 & 0 & 0 & 1 & 1 & 1 & 1 & 1 & 0 \\
\hline Богуслав & 0 & 0 & 0 & 0 & 0 & 0 & 0 & 0 & 0 & 0 & 0 & 0 & 0 & 0 & 0 & 0 & 0 & 0 & 0 & 0 & 0 & 0 & 0 & 0 & 0 \\
\hline Бориспіль & 0 & 0 & 0 & 0 & 0 & 0 & 0 & 0 & 0 & 0 & 0 & 0 & 0 & 0 & 0 & 0 & 0 & 0 & 0 & 0 & 0 & 0 & 0 & 0 & 0 \\
\hline Бородянка & 0 & 0 & 0 & 0 & 1 & 0 & 0 & 0 & 0 & 0 & 1 & 0 & 0 & 1 & 0 & 0 & 0 & 1 & 0 & 0 & 0 & 0 & 0 & 0 & 0 \\
\hline Бровари & 0 & 0 & 0 & 0 & 0 & 0 & 0 & 0 & 0 & 0 & 0 & 0 & 0 & 0 & 0 & 0 & 0 & 0 & 0 & 0 & 0 & 0 & 0 & 0 & 0 \\
\hline Васильків & 0 & 0 & 0 & 0 & 0 & 0 & 0 & 0 & 0 & 0 & 0 & 0 & 0 & 0 & 0 & 0 & 0 & 0 & 0 & 0 & 0 & 0 & 0 & 0 & 0 \\
\hline Володарка & 0 & 0 & 0 & 0 & 0 & 0 & 0 & 0 & 0 & 0 & 0 & 0 & 0 & 0 & 0 & 0 & 0 & 0 & 0 & 0 & 0 & 0 & 0 & 0 & 0 \\
\hline Вишшород & 0 & 0 & 0 & 0 & 0 & 0 & 0 & 0 & 0 & 0 & 0 & 0 & 0 & 0 & 0 & 0 & 0 & 0 & 0 & 0 & 0 & 0 & 0 & 0 & 0 \\
\hline Згурівка & 0 & 0 & 0 & 0 & 0 & 0 & 0 & 0 & 0 & 0 & 0 & 0 & 0 & 0 & 0 & 0 & 0 & 0 & 0 & 0 & 0 & 0 & 0 & 0 & 0 \\
\hline Iванків & 0 & 0 & 0 & 0 & 0 & 0 & 0 & 0 & 0 & 0 & 0 & 0 & 0 & 0 & 0 & 0 & 0 & 0 & 0 & 0 & 0 & 0 & 0 & 0 & 0 \\
\hline Кагарлик & 0 & 0 & 0 & 0 & 0 & 0 & 0 & 0 & 0 & 0 & 0 & 0 & 0 & 0 & 0 & 0 & 0 & 0 & 0 & 0 & 0 & 0 & 0 & 0 & 0 \\
\hline Kиï & 0 & 0 & 0 & 0 & 0 & 0 & 0 & 0 & 1 & 0 & 0 & 0 & 1 & 0 & 0 & 0 & 0 & 0 & 0 & 0 & 0 & 0 & 0 & 0 & 0 \\
\hline Макарів & 0 & 0 & 0 & 0 & 0 & 0 & 0 & 0 & 0 & 0 & 0 & 0 & 0 & 0 & 0 & 0 & 0 & 0 & 0 & 0 & 0 & 0 & 0 & 0 & 0 \\
\hline Миронівка & 0 & 0 & 1 & 0 & 0 & 0 & 0 & 0 & 0 & 0 & 0 & 1 & 0 & 0 & 1 & 1 & 0 & 0 & 1 & 0 & 0 & 0 & 0 & 0 & 0 \\
\hline
\end{tabular}

Рис. 5. Розміщення серверів (фрагмент таблиці)

\section{Розміщення серверів на площині}

На відміну від стандартної задачі, де $n$ вузлів є місцями-кандидатами на розміщення серверів, серед яких і треба вибирати, маючи матрицю вагових коефіцієнтів, у цій постановці треба відшукати такі місця будь-де, зокрема, поза заданих фіксованих вузлів, так би мовити, «у чистому полі». Ця умова суттєво ускладнює задачу, бо відповідна модель цієї задачі оптимізації належить до класу нелінійного (негладкого) програмування, де отримання глобального оптимуму не гарантується.

Приклад.

Матриця відстаней від шуканих серверів до $n$ вузлів-клієнтів графа формується за заданими координатами $(x, y)$ вузлів, $n=45$, треба визначити координати місць розташування $k$ серверів як центрів надання послуг, $k=4$, щоби кожен клієнт був прикріплений до одного зі знайдених центрів.

\section{Задача нелінійної оптимізації}

I. Знайти розміщення серверів у вигляді набору координат $\left\{x_{i}, y_{i}\right\}$ і матрицю призначення

$A=\left\{a_{i j}\right\}, i=1, \ldots, 4 ; j=1, \ldots, 45$, за якими

II. ЦФ $S=\sum_{i=1}^{4} \sum_{j=1}^{45} a_{i j} r_{i j} \rightarrow \min , \quad r_{i j}=\sqrt{\left(\left(x_{i}-x_{j}\right)^{2}+\left(y_{i}-y_{j}\right)^{2}\right)}$

III. за обмежень:

$$
\sum_{i=1}^{4} a_{i j}=1, j=\overline{1,45}
$$

та граничних умов: $a_{i j} \in\{1 / 0\}$. 
Результат представлено на рис. 5.

І. Розподіл:

— сервер z1 $(20,8 ; 45,0):(3,6,7,8,9,22,25,34,38,39), 10$ клієнтів;

— сервер z2 $(12,0 ; 14,0):(1,2,4,5,10,28), 6$ клієнтів;

— сервер z3 $(66,3 ; 76,8)$ : $(18,20,24,29,31,32,36,42,43,45), 10$ клієнтів;

- сервер z4 (50,8; 27,1): (11-17, 19, 21, 23, 26, 27, 30, 33, 35, 37, 40, 41, 44), 19 клієнтів.

II. Мінімальна вартість: $S=680,4$ од.

Отриманий результат дозволяє розв'язати непряму задачу із розбиття області розміщення/розподілу на кластери (рис. 6).

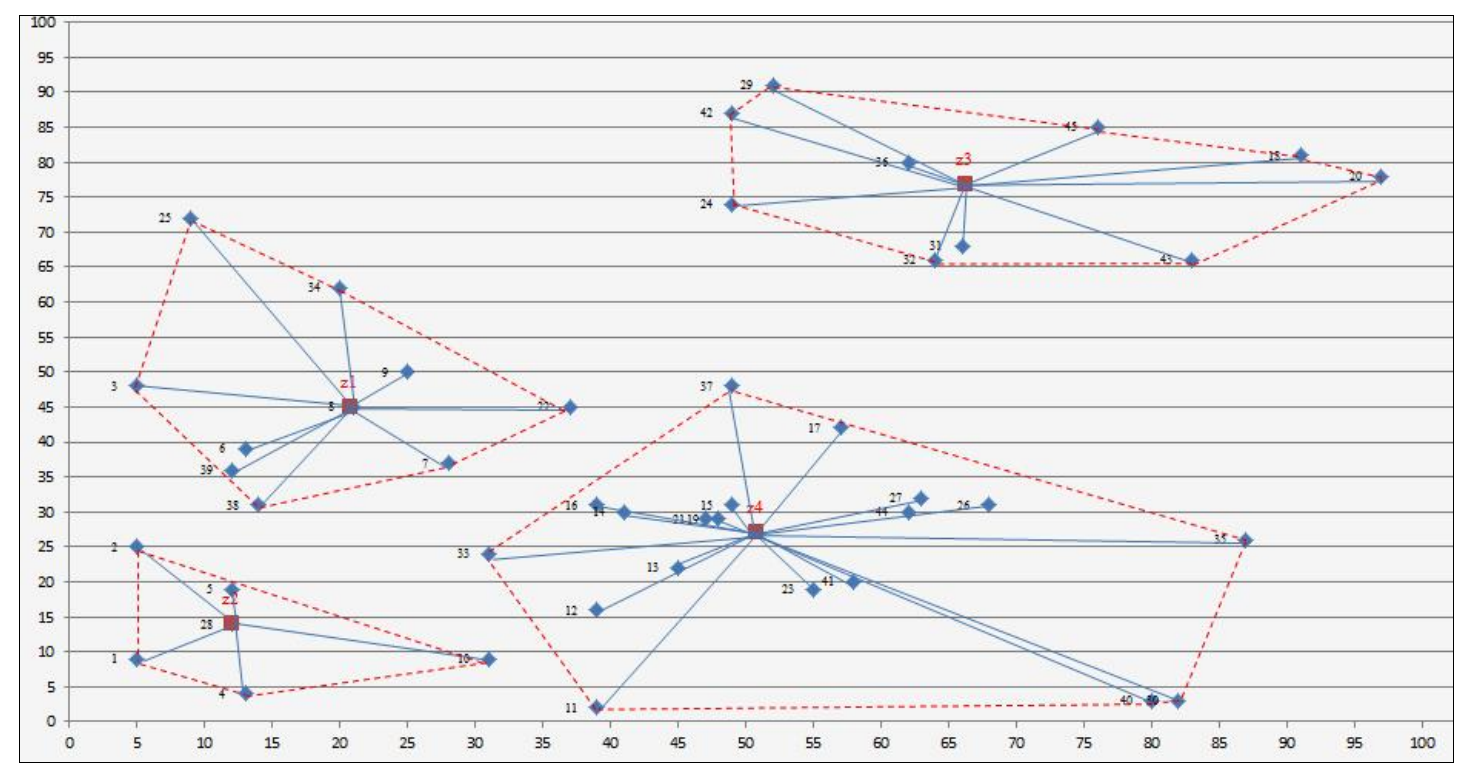

Рис. 6. Розміщення серверів, прикріплені до них клієнти та кластери

\section{Розміщення корисного центру на площині}

За критерієм мінімакс визначається розташування загального «гарного» центру (парк, банкомат, магазин, вокзал), за яким мінімізуються витрати для найвіддаленіших клієнтів, знайдені координати центру визначають так званий діаметр мережі - у відповідному колі сконцентровані всі ії вузли.

\section{Задача нелінійної оптимізації}

I. Знайти координати $\left\{x_{u}, y_{u}\right\}$ загального центру, за якими

II. ЦФ $S=\max _{i}\left(\sqrt{\left(\left(x_{i}-x_{u}\right)^{2}+\left(y_{i}-y_{u}\right)^{2}\right)}\right) \rightarrow \min$

III. за граничних умов: $x_{u}, y_{u} \geq 0$.

Приклад 5.

Результат: $\left(x_{u}, y_{u}\right)=(50,9 ; 43,7), Ц Ф=57,5$ од. (рис. 7). 


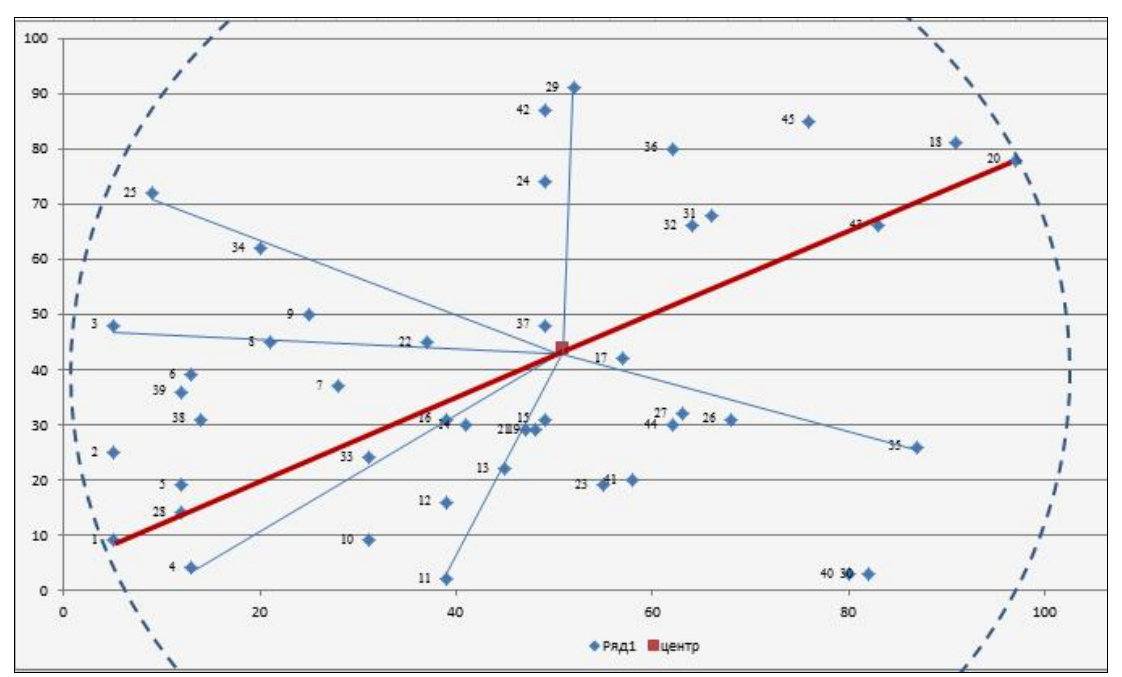

Рис. 7. Центр розміщення корисного сервера і діаметр мережі

\section{Розміщення небезпечного сервера на площині}

За критерієм максмін визначається розташування загального «поганого» центру (звалище відходів, полігон зберігання та переробки небезпечних речовин, ферма 3 відгодівлі худоби), за яким максимізуються відстані чи спряжені з ними витрати для клієнтів, вимушено розташованих найближче до майбутнього центру.

\section{Задача нелінійної оптимізації}

I. Знайти координати $\left\{x_{u}, y_{u}\right\}$ центру, за якими

II. ЦФ $S=\min _{i}\left(\sqrt{\left(\left(x_{i}-x_{u}\right)^{2}+\left(y_{i}-y_{u}\right)^{2}\right)}\right) \rightarrow \max$

за граничних умов: $x_{u}, y_{u} \geq 0$.

Приклад 6.

Результат: $\left(x_{u}, y_{u}\right)=(37 ; 62), Ц Ф=16,97$ од. (рис. 8$)$.

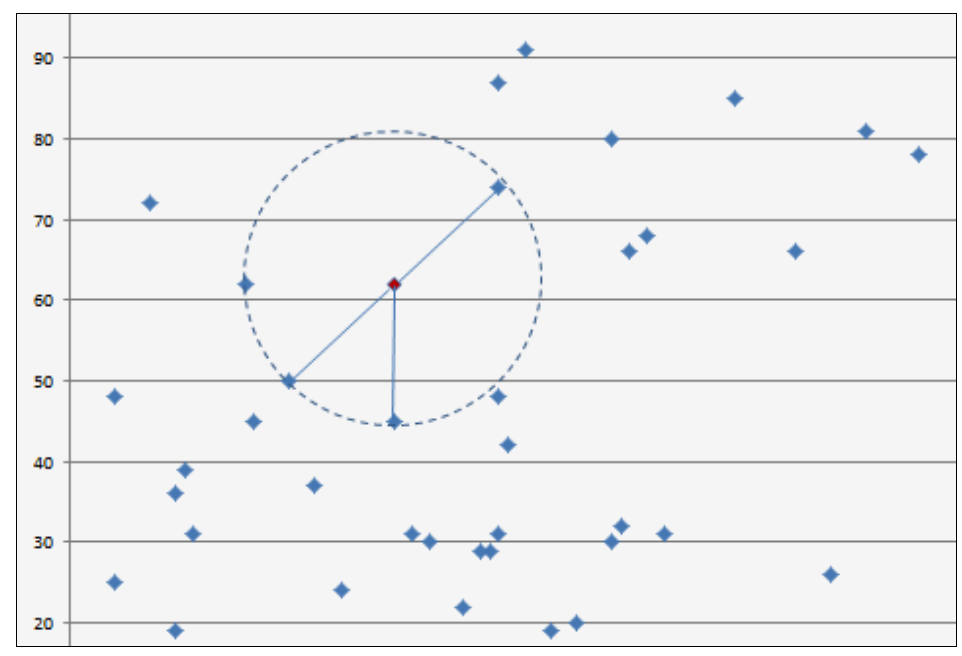

Рис. 8. Центр розміщення небезпечного сервера 


\section{Висновки}

Запропоновані оптимізаційні моделі задач розміщення серверів і прив'язки клієнтів до серверів реалізовані у середовищі електронних таблиць із застосуванням free-версій програм-розв'язувачів і розраховані на застосування будь-якою особою, що готує пропозиції щодо рішень, які мають прийматися, без необхідності купувати спеціалізовані комерційні пакети чи програмувати стандартні алгоритми. Ці моделі дозволяють оперативно врахувати певні специфічні властивості ситуації, що склалась у мережі, шляхом уведення відповідних додаткових початкових даних і обмежень.

1. Daskin M. Network and Discrete Location: Models, Algorithms, and Application. 2-ed. Wiley, 2013. $535 \mathrm{p}$.

2. Aiselt H., Marianov V. Foundations of Location Analysis. Springer, 2011. 524 p.

3. Aiselt H., Marianov V. Applications of Location Analysis. Springer, 2015. 440 p.

4. Teodorović D., Janić M. Transportation Engineering: Theory, Practice, and Modeling. Elsevier, 2017. $894 \mathrm{p}$.

5. Gass S., Fu M. Encyclopedia of Operations Research and Management Science. 3-ed. Springer, 2013. $1662 \mathrm{p}$.

6. Кузьмичов A.I. Аналітика мережевих структур. Моделювання засобами WinQSB та MS Excel: Практикум. Київ: Вид-во «Ліра-К», 2017. 215 с.

7. Baker K. Optimization Modeling with Spreadsheets. 3-ed. Thomson, 2015. 353 p.

8. Кузьмичов А.І. Оптимізаційні методи і моделі: Практикум в Еxcel. Київ: Вид-во Академії муніципального управління, 2013. 438 с.

Надійшла до редакції 08.06.2017 